\title{
ILCEA
}

Revue de l'Institut des langues et cultures

d'Europe, Amérique, Afrique, Asie et Australie

$31 \mid 2018$

Récits fictionnels et non fictionnels liés à des

communautés professionnelles et à des groupes spécialisés

\section{Narration in TV Courtroom Dramas: Analysis of Narrative Forms and Their Popularizing Function}

Récit narratif et séries télévisuelles juridiques : analyse des formes narratives et de leur fonction de vulgarisation

\section{Adriano Laudisio}

\section{OpenEdition}

\section{Journals}

Electronic version

URL: http://journals.openedition.org/ilcea/4685

DOI: 10.4000/ilcea.4685

ISSN: 2101-0609

\section{Publisher}

UGA Éditions/Université Grenoble Alpes

\section{Printed version}

ISBN: 978-2-37747-043-3

ISSN: 1639-6073

Electronic reference

Adriano Laudisio, « Narration in TV Courtroom Dramas: Analysis of Narrative Forms and Their Popularizing Function », ILCEA [Online], 31 | 2018, Online since 06 March 2018, connection on 01 May 2019. URL : http://journals.openedition.org/ilcea/4685; DOI : 10.4000/ilcea.4685

This text was automatically generated on 1 May 2019.

(C) ILCEA 


\section{Narration in TV Courtroom Dramas: Analysis of Narrative Forms and Their Popularizing Function}

Récit narratif et séries télévisuelles juridiques : analyse des formes narratives et de leur fonction de vulgarisation

\section{Adriano Laudisio}

\section{Introduction}

1 Narration has always attracted researchers and scholars committed to linguistics-see among others, Propp ([1928] 1958), Todorov ([1971] 1977), Genette (1972), Labov (1972, 1977), Bruner (1991), Altman (2008). Considered one of the innate forms of human expression, it has been investigated most obviously in literature, but also as a form of communication of knowledge and information. It is through storytelling, in fact, that knowledge, thoughts and beliefs have been transmitted from generation to generation throughout history. Narration is also traditionally associated with all forms of entertainment, stories being told for the pleasure of listeners, readers or viewers.

The fields of human activity pervaded by narration include legal discourse, where it plays a central role in the reconstruction of facts and judging their conformity to law. According to Altman, "stories constitute the bulk of sacred texts; they are the major vehicle of personal memory; and they are a mainstay of law, entertainment, and history." (2008: 1) Moreover, despite the variation of genres, narrations are created around a number of fixed elements such as a beginning, a middle and an end and one or more protagonists passing through a series of connected events leading to a final happiness or misfortune.

3 The unprecedented evolution of the media and the explosion of new forms of entertainment experienced in the recent years have led to an impressive production of novel forms of narration. Audiovisual products for cinema and TV fall within this 
category and currently represent, alongside traditional literature, the most important center for the production of narration. Among these, the different genres of FASP (Fiction à Substrat Professionnel) present the particularity of mixing specialized discourse and fictional narration. In particular, law-related fiction has established itself as the most popular form of multimedia FASP and the most popular professional branch, in terms of both volume and variety (Isani \& Chapon, 2015: 109).

4 The concept of FASP was originally introduced by Petit's (1999: 27-33) seminal work, which describes the genre as presenting the following basic constitutive elements:

1. "la caractéristique générale de raconter une histoire dont le lecteur a envie de connaître le dénouement (...). La qualité première d'un auteur est donc sa capacité à raconter une histoire; (...) le suspense en constitue un élément essentiel"; ${ }^{1}$

2. "Il résulte de ce qui a été dit de la profession du personnage principal et du point de départ de l'histoire que l'intrigue est, dans la FASP, essentiellement de nature endogène: elle se forme à l'intérieur du réel professionnel qui l'engendre". ${ }^{2}$

The last element refers to the specific professional or disciplinary environment which is central to the narration as it is part and parcel of the characters' fictional lives. More specifically, it can be said that the plot, the characters and the source of literary inspiration are defined by and dependent on a specialized professional environment ( substrat professionnel; Petit, 1999; Isani, 2004, 2006a, 2006b).

The telling of a suspense story, one of the central points in FASP and thus in legal drama, can take place in different ways. In fact, one of the criteria used to distinguish media genres is their narrative structure, i.e. the similarity in plots, situations, sequences, episodes, conflicts and resolutions (Chandler, 2000: 13). More specifically, on the basis of their narrative structure and plot continuity, three principal legal TV FASP sub-genres can be distinguished:

7 1) Serials: a single plot is narrated along a linear chronological development, and there is content continuity throughout the segments which compose them;

2) Series: episodes are generally not sequential to each other and feature the same narrative structure without radical changes in the characters ("circular" or "reiterative" development of the plot);

3) Serialized series: each episode features its own narrative thread which finds its conclusion within the episode ("vertical plot" or "anthology"); the episodes are nevertheless connected to each other by a narrative thread which creates plot continuity ("horizontal" or "running plot") as is the case of Suits and The Good Wife (Bernardelli, 2012: 23-36).

Within each episode, legal dramas often embed 'narrations within the narration', represented by the scenes in which the characters tell stories which are not presented to the audience as a series of images but through what the characters say, which thus becomes fundamental to the development of the plot (e.g. witness examinations and depositions).

In legal FASP television drama the professional background is represented by the fictional courtrooms and law firms in which the characters interact. The protagonists of the legal dramas under analysis here are lawyers, who are shown in "all the places they work and going about all their possible activities", while "they plead in courts, [...] meet clients, listen to and advise them, negotiate with other parties, do research in case law and prepare arguments" (Villez, 2005: 34-35). In general, the main characters face a series of 
extraordinary situations, placing their lives or personal safety in danger. They are given a case and their work is defined around investigating it. The reader is thus brought into the characters' professional environment (Petit, 1999: 30). It is important to bear in mind, however, that what distinguishes legal drama from reality shows or documentaries is the fictional element concerning lawyers' private lives, especially when these are linked to professional stakes. ${ }^{3}$

The appeal to the audience is central to determining the success of a series. In fact, in contrast to specialized and professional genres which are defined by the discourse communities which use them (Swales, 1990, Bhatia, 2004), media genres are not so much defined as specialized and professional genres by their producers as they are by their receivers: they are created in order to satisfy the audience, who have expectations about the genres and draw pleasure from recognizing known elements in what they see, while at the same time, expecting novel elements to surprise and entertain them. When such criteria are met, media genres become successful and establish themselves as independent genres. Therefore, they are not determined a priori or on a theoretical basis, but tend rather to be gradually established on a historical basis, being a "transformation of one or several old genres" (Todorov \& Berrong, 1976: 102, in Neale, 1990: 51) and are characterized by dynamism and volatility (Akass \& McCabe, 2007).

\section{Theoretical framework}

\subsection{Collection and analysis of the corpus}

11 This paper aims to reach two main purposes: first, to describe the forms narration can take in legal drama by underlining its centrality to plot development and in the reproduction of courtroom genres; second, to demonstrate the additional function of popularization of specialized contents and terminology served by it.

12 To this purpose, the transcripts of three TV series, The Good Wife (seasons 1 to 4, aired from 2009 to 2013 on CBS), Boston Legal (seasons 1 and 2, broadcast by ABC from 2004 to 2008) and Suits (seasons 1 and 2, broadcast by USA Network from 2011 to 2013), were downloaded from the website OpenSubtitles.org. A corpus of legal-specific scenes was then collected according to the following criteria:

13 - scenes set in a courtroom;

- scenes set in a law firm;

- scenes in which lawyers interact with peers, judges, law enforcement officers and clients;

- other scenes in which legal topics are discussed.

Scenes staging the private lives of the fictional characters and not concerned with the exercise of a legal profession were excluded from this analysis. Starting from the data collected, four sub-corpora were established for some of the main phases of trials and the most common forms of interaction between legal professionals and laypeople:

15 1) opening statements,

2) closing arguments,

3) witness examinations/depositions and

4) other lawyer-client interactions. 
16 In fact, seen in the perspective of ESP studies, legal drama is an example of "genre embedding", the form of hybridization in which a "particular generic form, it may be a poem, a story or an article [is] used as a template to give expression to another conventionally distinct generic form" (Bhatia, 1997: 191). Different genres, ranging from phases of the trial (preliminary hearings, opening statements, closing arguments, witness examinations, verdicts) to interactions between lawyers outside the courtroom or between lawyers and clients, are borrowed from the legal profession itself and are embedded in each episode (Laudisio, 2016a), or, as expressed by Bhatia (2004), "textinternal" and "text-external" resources of these specialized genres are "appropriated" and reproduced within a fictional frame to give birth to the plots narrated in legal FASP television series. Such appropriation is not limited to the lexico-grammatical level (e.g. use of legal terminology), but extended to the macro-levels of text structure and pragmatics. For instance, realistic representations of trials imply the reconstruction of the textual structures of the trial phase represented, which, as shown later, often include moments of narration. Of course, the narrations identified in legal drama are influenced by the 'persuasive' factor (since they often tell a certain version of facts in order to convince a jury or a judge) and by the 'fictional' factor, since they are not real and spontaneous reconstructions of facts but artificial scripts within an entertainment framework. It goes without saying that such reproductions of trials, created in a fictional context, may not be entirely representative of reality. For example, examinations in which witnesses are left free to speak or lawyers pose leading questions would probably be interrupted by the opposing party's objections.

17 The discursive features of the selected scenes were thus analyzed from two main perspectives, the first aiming to highlight the possible structures and shapes that narration takes within the general narrative frame of the TV series, and the second focusing on the "popularizing" function that narration can serve in legal drama.

\subsection{Overview of narration in legal discourse}

18 As mentioned, contrary to what may be commonly thought, law does not exclusively rely on abstract norms and logical reasoning, but also on narration. In the case of trials, for example, contextualization is essential to the reconstruction of facts. The stories narrated by lawyers attempt to organize events in a meaningful and plausible manner and as such is a universal feature of courtroom interaction. In fact, narratives are constructed all along the trial through the turn-taking sequences associated with courtroom interaction (Cammiss, 2006: 12-13). Others even consider that the "narrative glue" can be decisive in phases like the weighing of evidence (Brooks, 2005: 417). The whole trial is said to be a "contest of narratives" (Olson, 2014: 2) where a narrative and a "counter-narrative" (Cammiss, 2006: 11) constructed by the opposing lawyers are presented as two different versions of facts and the most convincing story wins over the other. The opposing narratives are given shape by lawyers who reproduce and present them to the judge or jury in an expressly constructed form which focuses on legally relevant details, in the awareness that the opposing lawyers will construct a counter-narrative with the aim to have their own version accepted by the court (Cammiss, 2006: 1-2). The acceptability of one narrative over another, moreover, is culturally based and influenced by "views about proper behavior, reasonable choices of action, and preconceptions about what is or is not acceptable" (Brooks, 2005: 419). 
19 A number of stylistic features specific to legal narration have been observed as pointed out by Cammiss (2006: 13), such as "flattening" (omitting irrelevant details), "sharpening" (exaggerating and emphasizing important points) and "rationalizing" (polishing other features of the narratives so as to remove unsuitable material). These features obviously cause narrative (re)productions in court to be partial and even to fail to reflect what actually occurred.

The following sections will show that the fictional narratives identified in legal drama tend to reflect the general structures and forms they show in real courtroom genres, such as opening statements, closing arguments and witness examinations, using narration in the same way as it is used in real courtrooms, i.e. with a persuasive function, as well as exploiting it as a means to popularize legal-specific contents and terminology to the audience.

\subsection{Popularization of legal discourse in FASP}

In this study, "popularization" is meant as

a vast class of various types of communicative events or genres that involve the transformation of specialized knowledge into "everyday" or "lay" knowledge, as well as recontextualization of scientific discourse, for instance, in the realms of the public discourse of the mass media or other institutions (Calsamiglia \& van Dijk, 2004: 370-371).

Popularization is thus based on a reformulation of specialized discourse so as to enable non-specialized readers to construct lay versions of specialized knowledge and integrate them into their existing knowledge. Moreover, in contexts such as the mass media, a recontextualization of scientific knowledge and discourse is required that differs from the specialized contexts where knowledge is produced. ${ }^{4}$

Many studies have focused on the popularization of specialized discourse and its recontextualization in different semi-professional, semi-specialized or lay contexts: Calsamiglia and van Dijk (2004) describe the strategies used to popularize new scientific discoveries about the human genome in a corpus of newspaper articles; Gülich (2003) analyzes the transcripts of oral conversations between doctors and patients and identifies different elements and types of reformulations and scenarios; similarly, Ciapuscio (2003) looks at oral interviews between scientists and specialized journalists and identifies, among others, popularization strategies like metaphors, exemplifications, concretizations, scenarios and reformulations. All these strategies are included in the studies by Garzone $(2006,2012)$ in which journal articles and the relation between news production and scientific knowledge are investigated and strategies like denomination and definition are described and exemplified in detail. Bamford (2012: 37) also identifies other linguistic strategies exploited in popularizing texts, such as selection, simplification, condensation, elaboration, re-arrangement, substitution, addition and deletion. With regard to legal drama corpora, analysis has led to the identification of similar strategies, with the addition of a number of genre-specific popularization devices, thus demonstrating the instrumental role played by legal drama in the popularization of technical knowledge to the non-expert audience (Laudisio, 2015, 2016a, 2016b) . $^{\text {. }}$ Narration, for instance, which represents some of the courtroom genres reproduced in legal drama, is employed as a means to catalyze the popularization of legal-specific 
concepts and terminology for the non-expert audience by means of shifts from narrative to definition in technical/specialized terms.

The co-existence of narration and abstraction in legal discourse is highlighted by Heffer (2005: 52), who distinguishes between "narrative" and "paradigmatic" mode ${ }^{6}$ in interactions between experts and non-experts (legal-lay discourse):

[Legal-lay discourse] involves a complex dialogic play between two broad ways of making sense of the world: one based on the subjective reconstruction of personal experience [narrative mode]; the other on detached analysis following logical principles [paradigmatic mode]. (My emphases)

The narrative mode is typical of reasoning based on "folk psychology" (Bruner, 1990: 35), which includes knowledge of the world and of life and what is generally also called "common sense".

The paradigmatic mode (or logico-scientific mode) stems from the possibility of writing and "fixing" in time what originally could only be narrated and referred to experience, in order to view contents in a timeless logic and within universal rules and principles. The narrative mode involves therefore a contextualization of the concepts, objects or facts described, while the paradigmatic mode operates a de-contextualization and explains concepts, objects and facts in terms of universal categories and principles.

Table 1. - Key strategies in the narrative and paradigmatic modes of reasoning (Adapted from Heffer, 2005: 23)

\begin{tabular}{|c|c|}
\hline $\begin{array}{l}\text { NARRATIVE MODE } \\
\text { (context-dependence) }\end{array}$ & $\begin{array}{l}\text { PARADIGMATIC MODE } \\
\text { (de-contextualization) }\end{array}$ \\
\hline \multicolumn{2}{|l|}{ Actional Strategies } \\
\hline Focus on the dynamics of the events & Focus on categories deriving from events \\
\hline Focus on human or human-like agency & Ignore agents, or classify them as categories \\
\hline Situate events in time and place & Abstract events from time and place \\
\hline Sequence temporally & Sequence logically \\
\hline \multicolumn{2}{|l|}{ Intersubjective Strategies } \\
\hline $\begin{array}{l}\text { Try to read into internal consciousness of } \\
\text { others }\end{array}$ & Deny what is not publicly tested \\
\hline Focus on subjectivity (intention, belief) & Focus on objectivity \\
\hline Show dialogic potential & Aim towards monologic view of truth \\
\hline Appeal to shared experience & Formulate and test hypotheses \\
\hline \multicolumn{2}{|l|}{ Normative Strategies } \\
\hline Follow constraints set by cultural canons & Follow constraints set by logical or legal canons \\
\hline
\end{tabular}




\begin{tabular}{|l|l|}
\hline Appeal to folk-psychology scripts and stories & Appeal to definition and logical deduction \\
\hline Focus on epistemic probability (likely to ...) & Focus on epistemic possibility and necessity \\
\hline Base validity on verisimilitude (lifelikeness) & Base validity on veracity (truth) \\
\hline Evaluative Strategies & Demonstrate logical or empirical truth \\
\hline Intensify the actional or intersubjective \\
\hline $\begin{array}{l}\text { Compare action and intersubjective with } \\
\text { canonical }\end{array}$ & $\begin{array}{l}\text { Compare demonstrable instance with definition } \\
\text { of class }\end{array}$ \\
\hline Use direct speech of narrative agents & Appeal to authority (e.g. through citation) \\
\hline Comment subjectively on narrative events & Comment objectively on analytical results \\
\hline
\end{tabular}

The interplay between the narrative and the paradigmatic mode is important to understand the popularizing function of narration in legal drama as a means of explaining technical terms and abstract concepts through concrete examples. It clarifies the stance taken by the producer of the narration and brings to the fore the alternation between "technical" and "popular" which, as can be seen in the last section of this paper, characterizes legal drama.

\subsection{Constitutive elements of narration}

The text structure of fictional trial reproductions in the corpus is analyzed on the basis of the "evaluation" model elaborated by Labov (1977), a methodological framework according to which the themes and structure of narration, in general and in the courtroom context, have been examined in several studies (among which Heffer, 2005). According to this model, a "complete" narration is made of six elements, generally in the sequence listed in the table below:

Table 2. - Labov's (1977) elements of narration (Adapted from Cammiss, 2006: 20-30)

\begin{tabular}{|l|l|l|}
\hline 1 & $\begin{array}{l}\text { An optional introduction with encapsulates the crux of the narrative. It is the } \\
\text { means by which the narrator makes it clear that normal turn taking } \\
\text { conventions are suspended and an extended turn will follow where the } \\
\text { narrator will tell the story. It is not strictly necessary in the mode of trial } \\
\text { hearings. }\end{array}$ \\
\hline 2 Orientation & $\begin{array}{l}\text { It is the step where the scene or context of the story is set by introducing } \\
\text { characters, locations, actions and relations. It provides answers to the } \\
\text { In the mode of trial hearings, where an abstract is rarely found, the } \\
\text { orientation clauses are often grouped together at the beginning of the } \\
\text { narration. }\end{array}$ \\
\hline
\end{tabular}




\begin{tabular}{|l|l|l|}
\hline 3 & Complication & $\begin{array}{l}\text { Answering the question "what happened then?", the complication is the main } \\
\text { body of a narrative and its only essential feature, although it can consist of } \\
\text { only a short string of narrative clauses. It includes the narrative clauses that } \\
\text { (re)produce past experiences and describe the events central to the narrative. }\end{array}$ \\
\hline Evaluation & $\begin{array}{l}\text { This informs the audience of the reason why the narrator is telling the story } \\
\text { by answering the question "so what?" and can include the narrator's } \\
\text { subjective observations. }\end{array}$ \\
\hline 5 & $\begin{array}{l}\text { This section may precede or follow the evaluation and informs the audience } \\
\text { of what finally happened to the central characters in the story: it is intended } \\
\text { as an answer to the question "what finally happened?". When it follows the } \\
\text { evaluation, it concludes the story by stating what finally happened and } \\
\text { connects it to the meaning of the narrative through the evaluative clauses. } \\
\text { In trial hearings, however, the result frequently precedes the evaluation, } \\
\text { since the result clauses often contain information which allow for evaluation } \\
\text { of the events. }\end{array}$ \\
\hline Coda & $\begin{array}{l}\text { The coda bridges the gap between the moment of time at the end of the } \\
\text { narrative and the present: it informs the audience that the narrative is at an } \\
\text { end. As opposed to the abstract, the coda operates so as to notify the audience } \\
\text { that the story has ended and the usual turn-taking conventions are } \\
\text { reinstated. It can sometimes be represented by a recommendation at the end } \\
\text { of the story. }\end{array}$ \\
\hline
\end{tabular}

Not all these phases are necessarily required: a narration may also be formed by only two narrative clauses and be equally effective. In particular, in the mode of trial hearings, the elements identified in Labov's model are not all present because institutional conventions determine the order and selection of speakers. Judges, for example, usually make an explicit request for the lawyers' statements and lawyers do not need to introduce their speech by means of an "abstract".

The forms of narration chosen depend on the specific phase of the trial and can largely differ from one another. Cammiss (2006: 30-41) operates a distinction among three main forms of trial narration:

31 1) full or complete narrative: the narrator speaks freely and continuously in such a way that the narration is a clearly distinguishable textual unit where Labov's phases are identifiable;

2) truncated or brief narratives: the narrator is interrupted, omits some narrative sections or reduces the narration to the minimum essential, losing the detail of full narrative;

3) no narrative: cases in which prosecutors do not deliver a narrative as it is commonly understood, in other words without a sequence of narrative clauses but by means of other elements. corpus of transcripts of witness examinations are analyzed and classified as follows:

1) free narrative: where the witness answers an open question and narrates freely, usually embedding all Labov's phases. These are almost absent in the corpus;

2) extended narrative: witness turns of more than 100 words in length which contain at 
least two temporally-connected narrative tense verbs. These amounted to $0.1-0.9 \%$ of the cases under analysis;

3) the "show and tell" mode: a kind of hybrid narrative in which the lawyer is divided between showing (speaking to the jury through witnesses) and telling (speaking to them more directly).

The choice of the narrative form depends on factors like the lawyer's personal style, speaking time allotted according to trial and courtroom conventions and, of course, the type of offence involved. For example, the most truncated narratives are delivered for the simplest cases dealing with the most common offences, in which the judge is in possession of a sufficient "stock of knowledge" and does not find it necessary to list any more details; on the other hand, in more complex cases where the opposing parties report different versions of the facts, a more complete narrative is both expected by the judge/jury and exploited by the prosecutors.

The following sections of this study will examine the occurrence of the different forms of narrative proposed above within the different fictional reproductions of courtroom subgenres present in the corpus.

\section{Data Analysis: Full narrative in legal FASP television series}

\subsection{Full narrative in deposition}

As indicated above, full narratives are not frequent in court hearings, especially during witness examinations (Heffer, 2005). However, some examples can be found in legal drama, where the fictional nature of the genre contributes to the higher presence of more traditional narrative structures supposedly to help the audience follow the plot. The following scene, for instance, is a deposition taken from the legal FASP television series Suits, in which the witness Monica Eton (herself a lawyer) is left free to tell the story during a recorded deposition taken at the company where she used to work. The reason for this is that her lawyer, ex-boss and ex-lover Daniel Haltman, aims to reconstruct in her favor the situation which led to her firing:

Table 3. - Full narrative in fictional deposition

\begin{tabular}{|c|c|c|}
\hline \multicolumn{2}{|r|}{ Deposition } & Labov's phase \\
\hline \multirow{2}{*}{$\begin{array}{l}1 \\
2\end{array}$} & \multirow{3}{*}{$\begin{array}{l}\text { Q: Harassed? By who? } \\
\text { A: I was being harassed by Louis Litt. (...) } \\
\text { He asked me out repeatedly, after I rebuffed }\end{array}$} & Abstract \\
\hline & & \multirow{3}{*}{ Orientation } \\
\hline 3 & & \\
\hline \multirow{2}{*}{$\begin{array}{l}4 \\
5\end{array}$} & \multirow{2}{*}{$\begin{array}{l}\text { He would stare at me, wait at the elevator outside my office, the diner, } \\
\text { everywhere. He was partner, and I had to say 'no' to him. }\end{array}$} & \\
\hline & & Complication \\
\hline \multirow{2}{*}{$\begin{array}{l}6 \\
7\end{array}$} & And it made me feel disgusting every single day. & Ev: \\
\hline & \multirow{3}{*}{$\begin{array}{l}\text { Q: Will people corroborate your account? } \\
\text { A: It was common knowledge within the firm. (...) } \\
\text { Q: Monica, I have one more question for you. To whom did Jessica tell you } \\
\text { to hand in your resignation? }\end{array}$} & Orientation \\
\hline 8 & & \\
\hline & & $\begin{array}{l}\text { Result } \\
+ \text { Evaluation }\end{array}$ \\
\hline 11 & \multirow{2}{*}{$\begin{array}{l}\text { A: Louis Litt. } \\
\text { Q: So in conclusion, you were being sexually harassed, it was well-known, }\end{array}$} & \\
\hline 11 & & Lawyer's \\
\hline 12 & Jessica Pearson dismissed you, and you were actually told to hand in your & \\
\hline 13 & resignation to the very man who did the harassing. & narration \\
\hline 14 & $\begin{array}{l}\text { A: Yes. That statement is entirely true. } \\
\text { (Suits } 2 x 14 \text { ) }\end{array}$ & Coda \\
\hline
\end{tabular}


in Labov's (1977) perspective, the lawyer's question in line 1 can be considered the "abstract" of the narration, since it triggers the narration and signals its beginning to those listening. The answer given by the witness (line 2) serves as a conjunction between the abstract and the actual orientation, describing the general background in which the narration is set and thus signalling its beginning. Lines 3-4 mark the actual beginning of the narration, presenting locations (the elevator outside my office, the diner, everywhere), characters (Louis Litt and the witness herself), and especially their actions. The complication follows when the witness says what happened when, after being courted for a while, she had to say no to him (line 5). Some orientation elements are added to the narration as a consequence of the lawyer's questions, as in lines 7-8, where the witness adds new characters to the narration (all their colleagues in the firm) and presents the condition of harassment as being of common knowledge. The result of the narration is provided as an answer to the lawyer's question (lines 9-10). Elements of personal evaluation are embedded in various points along the narration, like in line 6 , just after the complication, where the witness explains the reasons leading to her actions, and in the lawyer's question in line 9, where the rationale of the narration and the link to the harassment cause can eventually be deduced. which contains a sequence of clauses made up of more than two narrative verbs (the minimum for a narration according to Cammiss, 2006: 20), in which we can distinguish an incipit which signals the beginning of the narration acting as an abstract (So, in conclusion ), two orientation clauses (you were being sexually harassed; it was well-known), a complication (Jessica Pearson dismissed you) and a result (you were actually told to hand in your resignation...). The coda of the whole narration is represented by line 14 , where the witness confirms the lawyer's reconstruction of the facts and the examination is interrupted.?

It is therefore possible to construct a fully-fledged narration in the context of a fictional witness examination, both as a cooperative reconstruction enacted by the lawyer and the witness in the question-answer exchange, and as a short (but effective) narration given by the lawyer alone. In both cases, although much space is left to a reconstruction of facts which is instrumental to the development of the plot and of the whole episode, the main discursive features of depositions are successfully reproduced.

\subsection{Full narrative in opening statements and closing arguments}

The analysis of the corpus brings to the fore that full narratives are more frequent in other phases of the trial, namely the monologic sequences specific to lawyers: almost all the opening statements and the closing arguments in the corpus contained narrative elements, including a number of fully-fledged ones, as can be seen below: 


\begin{tabular}{|ll|l|}
\hline \multicolumn{2}{|c|}{ Opening statement } \\
\hline 1 & She came home that evening at 9:30, catching an early flight to surprise & Orientation \\
\cline { 2 - 3 } 2 & her husband. But it was the defendant who was surprised. & Evaluation \\
\cline { 2 - 3 } 3 & Susan May discovered her husband, Ralph, making love to a business & Complication \\
4 & associate Marie Holcomb... and it was more than she could bear. \\
5 & The evidence will show that the defendant, retrieved a handgun from \\
6 & the kitchen, retumed to the bedroom and fired six shots: & \\
7 & three into her husband, three into Marie Holcomb. & Result \\
\cline { 2 - 2 } & & \\
\hline
\end{tabular}

41 An opening statement is a monologic oral address delivered by the lawyer to the jurors. Although its official function is to introduce the jury to the facts and the people involved in the case and thus provide an explicative and descriptive overview of the evidence which will follow, it has been defined as a form of "persuasive monologue" (Chaemsaithong, 2014: 757) for the possibility it offers to both parties to construct and provide their own versions of the facts. Although there are some constraints regarding the form of opening statements-they cannot contain personal opinions or references to inadmissible evidence, for example-, it has been demonstrated that they can significantly influence the outcome of a trial (Lindquist, 1982, quoted in Cotterill, 2003: 65), or at least contribute to creating a "framework through which jurors filter the subsequent presentation of evidence" (Spiecker \& Worthington, 2003: 437). Because of their persuasive function, which is fulfilled alongside the expository/informative one, opening statements often resort to a carefully structured narrative, generally consisting of five (non-mandatory) rhetorical moves:

42 1) introductory remarks;

2) introduction of witnesses, places, instrumentalities involved;

3) identification of major issues or contentions;

4) telling the story;

5) conclusion and request of a verdict.

43 The five steps identified by Tanford (2002: 162) largely correspond to Labov's (1977) elements of narration. As Table 4 above shows, the entire opening statement can, in fact, be a narration. The characters and the setting are introduced directly (see lines 1-2), without an abstract, since the sequential order of trial phases is enough to announce the beginning of a narrative moment. The rationale of the narration (evaluation), which reveals the narrator's personal stance, is given immediately after, thus raising curiosity ( But it was the defendant who was surprised, line 2). The complication follows, with the crucial event causing the criminal behavior (lines 3-4), while the results correspond to the version of the facts proposed by the lawyer (lines 5-7). These lines also implicitly act as a coda, since they signal the end of the narration by making reference to the evidentiary phase which will follow (The evidence will show that..., line 5). 


\begin{tabular}{|l|l|l|}
\hline \multicolumn{2}{|c|}{ Closing argument } \\
\hline 1 & This man, who suffers day in and day out, migraines so excruciating he & \\
2 & cannot work, can't endure 10 minutes at his computer. A trained software & Orientation \\
3 & engineer... And here he is, subjecting himself to depositions, & \\
4 & to examinations, to the laborious, mind-numbing blather of attomeys. & \\
5 & All for what? Frivolity? & \\
& For six months Bill Morgan reached out to his doctor, week after week, & Evaluation \\
\cline { 3 - 3 } 7 & each time invoiced for thousands and thousands of dollars in sum. And & Complication \\
8 & then each time dismissed, patted on the head and sent on his way. & \\
9 & Had Mr. Morgan actually received the right medical care, or even been & \\
10 & directed to a doctor who could specifically give him that care (...) his & Evaluation \\
11 & current state would most likely have been alleviated. & \\
12 & But the defendant couldn't be bothered to care. & Evaluation + \\
13 & As Dr. Raybum told you himself, he treated Bill Morgan like a mascot. & Result \\
14 & Opposing counsel regards him as a nuisance. He's a human being! & \\
& Boston Legal, Ix05) & \\
\hline
\end{tabular}

Like opening statements, closing arguments are a monologic genre delivered by the lawyer, but unlike opening statements, they overtly serve a persuasive function. As they are the last phase before the instructions to the jury, they can serve the function of deconstructing the opposing version of events:

The advocate can point out the incoherence and implausibility of the competing account and the opponent's failure to keep his or her premise to present adequate evidence to support the story told in the opening statement (Burns, 2009: 25-26).

According to studies conducted by Aron et al. (1996, in Anesa 2011: 173), the phases identified in closing arguments do not necessarily include a narration, but focus more on what the jury should bear in mind in order to reach a fair verdict:

1) Introduction, in which the crucial issues are emphasized;

2) Development of the argument, including a review of relevant evidence;

3) Discussion of the legal principles related to the case;

4) Conclusion, which guides the jury towards a favorable verdict.

The example in Table 5, in fact, shows that the narrative mode can adapt to closing arguments, but the numerous evaluative elements contained give the narration a more personal tone. Evaluation is first expressed in line 5 , when the rhetorical question posed by the lawyer (All for what? Frivolity?) acts on the meta-discursive level and explains the reasons why the facts narrated in the orientation are directly related and have resulted in the case being discussed. The events are arranged in chronological order in the complication (lines 6-8), which is followed by other evaluative elements: the lawyer comments on the characters' behavior by means of a hypothetical construction emphasizing the opposing party's wrongful behavior; he explains the reasons for which his client is suing his doctor and acts on the jurors' conscience as a persuasive device. The opposing party is also criticized in the last lines of the speech, where the use of emotional language replete with metaphors and rhetorical devices brings the narration to its conclusion.

48 From the analysis of these excerpts it is clear that the fictional closing arguments and opening statements reproduced in legal drama after the model of 'real' trials largely rely upon elements of narration. However, such elements of narration alternate with elements of persuasion which reveal the argumentative nature of the narrations. Moreover, narration is molded according to the conventional form and structure of the courtroom 
shaped by institutional/professional norms. They are therefore hybrid narrations, adapted to context and purpose.

\subsection{Truncated narrative: through/despite a witness}

More predictably, witness examinations generally lead to truncated narratives, since witnesses' narratives are strictly controlled by the questions of the trial lawyer (Cammiss, 2006: 41). Likewise, since witnesses' answers must be relevant to the question posed by the lawyer, they can rarely expand into full narrations, especially in cross-examinations. The reconstruction of the story, therefore, takes place in a series of exchanges between the interlocutors and not by means of a sequence of temporal clauses pronounced by one speaker, as illustrated in the two examples below:

Table 6. - Truncated narrative in witness examination (constructing stories through the witness)

\begin{tabular}{|c|c|c|}
\hline \multicolumn{3}{|c|}{ Witness examination \#l: Mike Ross } \\
\hline & Q: What time had you called for the limo on the morming of the accident? & Orientation \\
\hline & A: Uh, we were supposed to leave at $8: 30$. & \\
\hline & Q: And what time did you get to work? & Complication \\
\hline & A: $8: 40$. & \\
\hline $\begin{array}{l}5 \\
6\end{array}$ & $\begin{array}{l}\text { Q: So unless Mr. Benghazi made up for that lost time, you were going to } \\
\text { be late for that meeting, correct? }\end{array}$ & $\begin{array}{l}\text { Evaluation + } \\
\text { Result }\end{array}$ \\
\hline & A: Yes. & \\
\hline 8 & -No further questions, Your Honor. [...] & Coda \\
\hline
\end{tabular}

Table 7. - Truncated narrative in witness examination (constructing stories despite the witness)

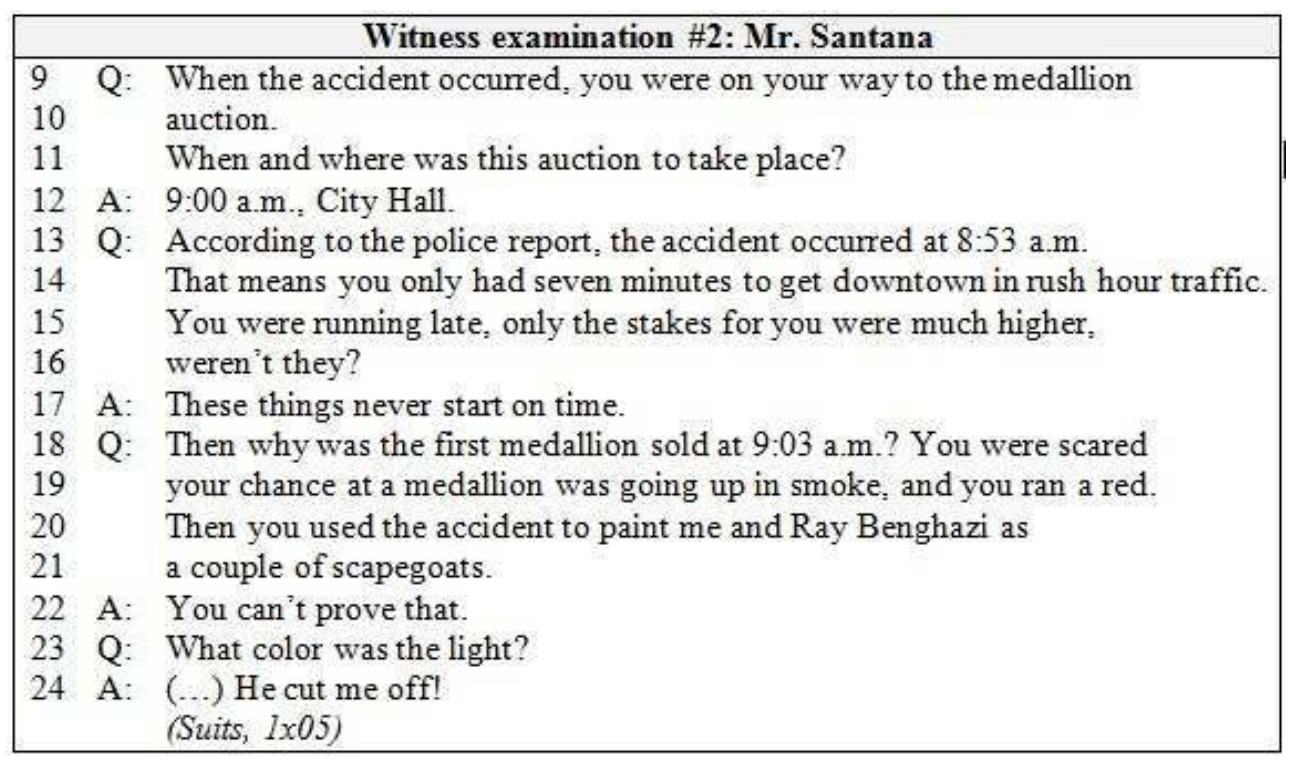

50 These two scenes are drawn from the same trial represented in episode 1x05 of Suits. In this episode, the two lawyer protagonists, Mike Ross and Harvey Specter, have a car accident when their limousine, driven by Ray Benghazi, hits a taxi, driven by Mr. Santana. The taxi driver is accused of not stopping at the red traffic light because he wanted to attend a taxi medallion auction. In Mike Ross's testimony in Table 6, the story is reconstructed in the lawyer's favor, because Mr. Santana, who has decided to act as his own lawyer in the lawsuit, manages to push the two lawyers to admitting that they would 
have been late for work in any case. The orientation is represented by the opening lines (1-2) describing the initial situation which, however, was changed by their delay, resulting in the complication (lines 3-4). The inferences produced by the complication (that the two lawyers would have been late because they got to work at 8.40 instead of 8.30) represent the potential result of the complication: hypothetically speaking, if the two lawyers had not had the car accident, they would have been late for work anyway because of their own delay, a fact which relieves Mr. Santana of any responsibility regarding the car accident. Mr. Santana, therefore, is able to reconstruct and narrate the facts in his own favor through the words of the witness, who acts as a narrator.

51 In the second excerpt (Table 7) narration does not take place in a conventional manner and Labov's phases are not clearly distinguished. The lawyer's questioning does open up with some elements of orientation (locating the accident, locating the characters at the moment of the accident and making their intentions explicit, lines 9-17), but at the same time elements contained in his question reveal the rationale behind his questions (The accident occurred at 8.53. That means you only had seven minutes to get downtown in rush hour traffic, lines 13-14) and therefore implicitly constitute the 'evaluation' in this narration. The "complication" of the action is first represented by the defendant running a red as hypothesized by the lawyer (line 19), but is only made clear to the audience in line 24, when the witness sustains that it was the limousine that "cut him off". Therefore, the "complication" is only revealed after the "result" of the story (Santana causing the accident and using it as an excuse for being late for the medallion auction, lines 20-21), while the rationale of the narration is expressed by the various arguments sustained by the lawyer in further points during the examination. ${ }^{8}$

Similar to the case commented above, Harvey Specter has been able to reconstruct his version of the facts using the witness' words, although he does not use the witness' narration in his favor, but operates to destruct his declarations and brings him to admit his wrong. He is thus not only narrating his own story "through" the witness, but also "despite" the witness's initial statements.

\subsection{No(n-conventional) narrative}




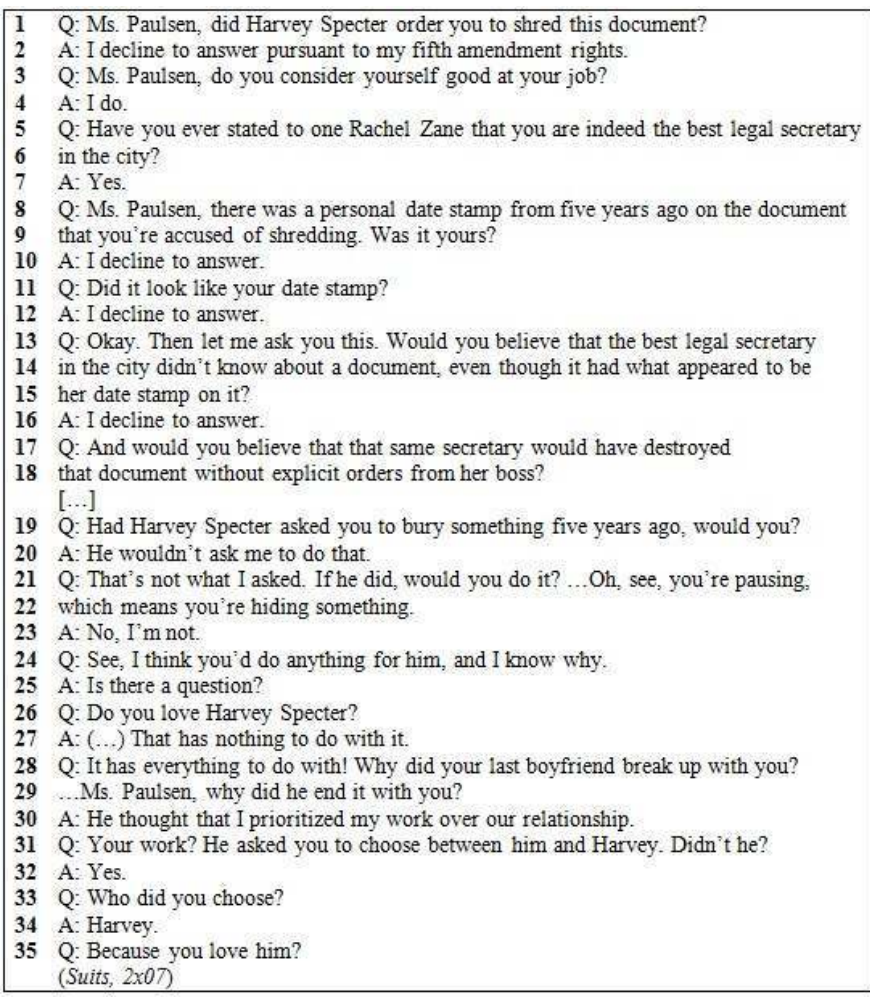

This excerpt shows how facts can be reconstructed and "narrated" to the audience in a non-conventional communicative situation. During a mock trial (i.e. the reconstruction of a potentially real trial for educational purposes, or organized by a law firm to choose the right defense strategies), the lawyer, Louis Litt, is questioning Harvey Specter's secretary, Donna Paulsen, in order to find out if she had destroyed a document to protect Harvey, motivated by her love for him. Although Donna is clearly hostile and attempts to hide behind the right to stay silent by pleading the Fifth Amendment, Louis achieves his purpose of making her look guilty in the eyes of the jurors (and the audience). The dialogic exchange between the two is unbalanced: Donna refuses to answer four times (lines 2, 10, 12 and 16), and pauses once (line 21), attempting to shift the focus of the question instead of answering potentially inculpatory questions; on the other hand, Louis Litt is left free to formulate questions in such a way as to make her appear as being involved in the crime and even to draw personal conclusions (You're pausing, which means you're hiding something, lines 21-22), expressing personal thoughts (I think you'd do anything for him, and I know why, line 24; Because you love him, line 35), and to formulate full hypotheses about the events by means of rhetorical questions (Would you believe that the best legal secretary..., lines 13-15). The power bestowed on the lawyer by the communicative context and his institutional role is reflected at the discursive level and allows him to convey his version of facts despite the witness' intention.

Bearing in mind that such a line of questioning would be interrupted by a series of objections if it were not a mock trial (for example, the counsel badgers the witness more than once), we can observe a non-conventional narration: in theory, questions asked by the lawyer are meant to receive confirmation from the witness regarding the facts and herself and would therefore all constitute the "orientation". Moreover, the narration is not brought to an end, since after posing questions about the documents and Donna's 
professional skills, Louis shifts the topic of the conversation towards Donna's previous love relationship and her private life. It is thus difficult to identify a complication of the initial situation described at the beginning of the examination or to clearly identify the result of someone's actions and a finale of the narration. However, the questions asked and the missed answers are enough to frame Donna and to make both the jurors and the audience infer that she was in love with Harvey and had broken up with her ex-boyfriend for him, that she knew about the document in question, she had even put her stamp on it and that when she realized that it was a threat for Harvey, she had destroyed it. In other words, the lawyer has been able to construct and provide his version of the facts despite the witness' intentions and without resorting to narration.

\section{Narration as a popularization strategy}

As said above, FASP genres are largely based on a specialized context, which permeates almost all elements of the narration. In the case of legal TV series, lawyers have to deal with complicated cases and find strategies to protect their clients and convince the jury or the judge. Law is often questioned and investigated, different strategies are listed, taken into consideration and presented to the viewers. However, most concepts and terms pertaining to law and courtroom procedures are opaque to the general audience and in some episodes can reach high levels of specialization, often embedding professionspecific expressions, crystallized metaphors, acronyms etc. (Laudisio, 2016a). It is thus necessary to combine specialized discourse and a number of linguistic devices aimed at making such specialized discourse accessible and comprehensible to laypeople. Isani (2009: 50-59), for instance, showed how witness examinations can be exploited in legal FASP novels for the explanation of legal-specific concepts by means of questions such as "Would you explain this rule to the jury?", "What does 'the M'Naghten Rule' mean?", "Could you simplify that?" and purposely-constructed answers which provide information and examples about the item of discussion. Following Isani's trail, my own studies $(2015,2016 \mathrm{a}, 2016 \mathrm{~b})$ showed that the authors of legal FASP television series specifically employ linguistic strategies aimed at expressing technical contents in simpler words for the lay audience. Besides the most typical popularization strategies (among which definitions, reformulations and metaphors), the use of narration is also exploited as a means to explain legal-specific contents as illustrated by the excerpts below: 
1 Alicia: We move to disqualify the video on the grounds that it was obtained as the result of an illegal arrest.
Matan Brody: Your honor, what could possibly be illegal...? (..)

4 Alicia: Officer Sutton stated on his dashboard video: 'Don't make me put the

5 handcuffs back on you', implying that he'd been handcuffed previously.

6 Judge: Did you, officer Sutton?

7 Officer Sutton: I'd handcuffed him when I found him in the bar because he was

8 belligerent, as you see in the video. But when I brought him outside, I took the cuffs

9 off so I could perform a sobriety test.

10 Alicia: Was Mr. Stem armed?

11 Officer Sutton: No.

12 Alicia: Did you fear for your life?

13 Officer Sutton: No, but, I...

14 Alicia: Then it was an arrest, your honor. Mr. Stern was not free to go.

15 And officer Sutton had no probable cause. The mere fact that it was an accident

16 does not mean a crime was committed. So everything that follows is tainted,

17 the sobriety tests, the video. (The Good Wife 1x09)

Table 10. - Personal narration as a popularization strategy

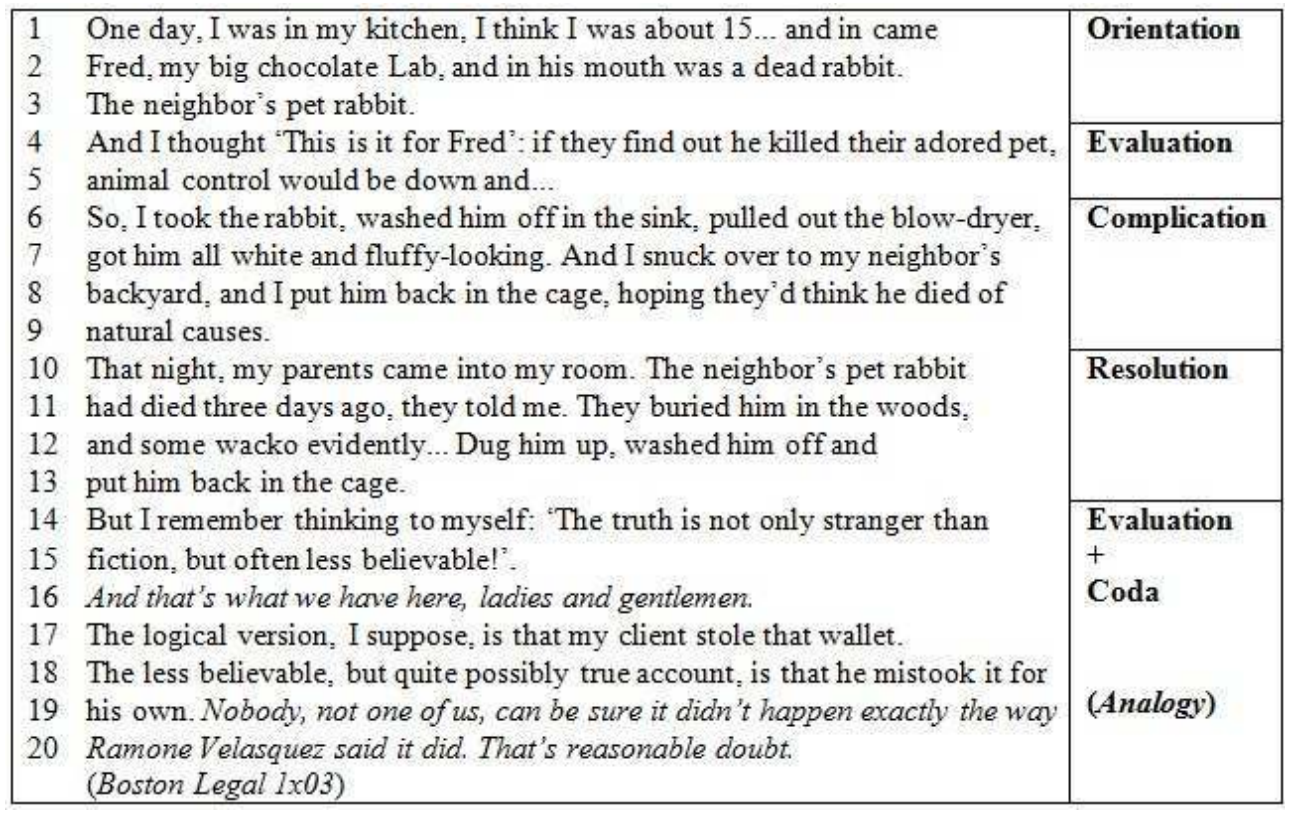

56 The example in Table 9 shows how a narration can be instrumental in understanding why an arrest has been carried out in an illegal manner and helps the lawyer in her client's defense: the actions are described and placed in chronological order by the use of different past tenses (Past Simple, Past Perfect, etc.), cause-effect relations are made explicit and the whole narration is reformulated in legal-specific terms when the police action is labelled as an "illegal arrest" where officer Sutton had "no probable cause".

57 The example in Table 10, on the other hand, is taken from a closing argument and compares a story drawn from the lawyer's personal experience with the case under discussion, introducing the concept of "reasonable doubt" and triggering a reflection on how often facts can differ from how perceived at first sight. Though it differs from the 
example in Table 9 in that it is not directly related to the lawsuit under discussion, it serves the same "popularizing" function as the introduction of personal narrative to help understand an unrelated issue found in fables and parables.

The narrative mode can also be instrumental in popularizing technical contents if associated with the "paradigmatic" one. As said above, in legal discourse a "complex dialogic play" (Heffer, 2005:3) takes place between these two modes of expressing meaning: on the one hand, the tendency to abstract and decontextualize is typical of legal doctrine, written rules and regulations; on the other, specific details are required and can prove to be essential in handling courtroom cases. The following example shows how the interplay between the narrative and the paradigmatic mode can help popularize legalspecific terms and concepts and why it is constitutive of the legal drama genre:

Table 11. - Narrative-to-paradigmatic as a popularization strategy (example 1)

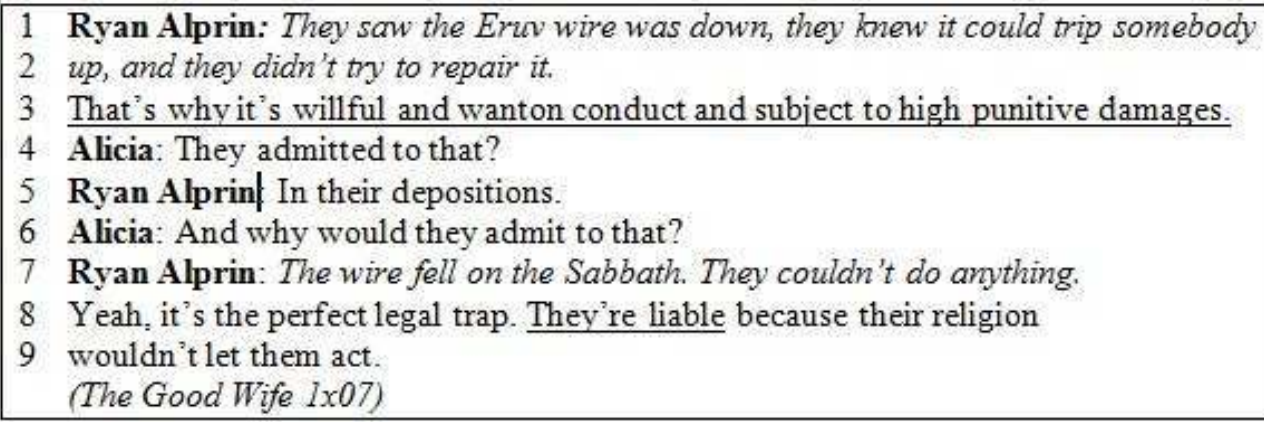

While asking his colleague Alicia Florrick for advice, the lawyer Ryan Alprin condenses the facts into a short but effective three-clause narration (lines 1-2), to which some orientation elements are later added (line 7). In so doing, he situates the facts in time and place (The wire fell on the Sabbath), focuses on the dynamics and the sequence of the events (the defendants seeing the wire and not repairing it), on their (non-)agency (knowing it was dangerous but not removing it), and finally considers their internal consciousness, their intentions and beliefs trying to identify the rationale behind their actions (Why would they admit to that? The wire fell on the Sabbath. They couldn't do anything, lines 6-7). These actions are all typical of the narrative mode (see Table 1). However, by relating these facts to what is established by law, he operates a shift from the narrative to the paradigmatic mode: he defines the actions carried out by the defendants as "willful and wanton conduct" by giving it a definition and a category and immediately after, reveals the potential consequences envisaged by law (subject to high punitive damages, line 3). Ryan Alprin is resorting to definitions and, as such, is following the constraints imposed by logical and legal canons and considering the consequences for the wrongful actions in an abstract, objective manner. All these actions are the expression of the paradigmatic mode. The shift from narrative to paradigmatic is thus an effective strategy to implicitly explain legal concepts (paradigmatic categories) by means of contextualization, exemplification and narration. 
1 Denise: Unfortunately, the H.MO., Well Benefits, posted Jackie 's information, including the name and

2 address of the psychiatrist, on their website. Emily's father found Jackie's psychiatrist via the

3 Well Benefits Web site... and tracked her down at the psychiatrist's office.

4 Emily: And that's where... He killed her.

5 Alan: So this is a wrongful death action. Boston Legal (2x13)

60 Similarly, the example in Table 12 shows the conversation between two lawyers (Denise and Alan) and a client, Emily, where narration is central. The interaction between the three provides the audience with an example of "wrongful death action": Denise meets Alan and introduces him to a new case which is being brought to his attention. She helps reconstruct the context, including descriptions of individuals involved, their actions, time and places of the facts, but does not specify what kind of lawsuit it is, which laws regulate it or which defense strategies can be used in courtroom. In fact, the "switch" to the paradigmatic mode is left to the other lawyer, Alan, who, being a law expert, is able to connect the facts narrated to a specific type of lawsuit (So this is a wrongful death action, line 5) and consequently to what they should do as legal professionals.

61 These examples show that, similar to definitions, reformulations or paraphrases, the technical term can be juxtaposed to a narration which serves the role of explaining it by providing an example. The audience is placed before a narration which does not only develop the plot and relate facts which are not depicted, but also identifies and designates them from the perspective of law and by using specific legal terminology. It is, therefore, in the passage from the narrative mode to the paradigmatic one (represented by the classification into a type of law or lawsuit, the correspondence to a technical concept or term) that specialized knowledge is transmitted. It has to be borne in mind, however, that the "quantity" and "quality" of the information intended for the audience is only what is necessary for the purposes of a fictional product basically designed to entertain.

\section{Conclusions}

The analysis of the samples drawn from the corpus has shown that narration is central to legal drama at two levels, firstly as an intrinsic element of legal FASP television drama as a whole in that each episode of the series tells a story and, secondly, as an element specific to each courtroom genre reproduced in a fictional key.

The observation of the six phases of Labov's (1977) model has shown that although "real" trials rarely host full narration (Heffer, 2005), fictional reproductions of certain trial phases do allow for this form of narration. It has been shown, in fact, that full narrations (i.e. those where all six of Labov's constitutive elements are identified) can be developed both as a cooperative reconstruction in the question-answer exchange between lawyer and witness, and as a short (but effective) narration given by the lawyer alone.

Similarly, full narrations can be found in closing arguments and opening statements, which often rely upon elements of narration in real trials as well. Although samples of full narration can be identified, they are usually hybridized: for instance, narration in closing arguments is permeated by persuasive elements, while in witness examinations it is influenced by the lawyer's attempts to build a version of facts which diverges or 
converges with the one proposed by the witness. In witness examinations, opening statements and closing arguments, narrations generally only represent a fragment embedded within a larger speech or dialogue; in most cases, they are a part of more complex, hybrid genres embedding summaries, evidence showing, persuasive elements and interrogations.

The instrumental function served by such genres within the institutional context in which they are used results in a more common use of "truncated" rather than full narrative: through the question/answer pattern of witness examinations, the authors of legal drama manage to tell a story through the characters' words, presenting the audience with the elements composing the story in more steps. In all these narrations, the narrators are mixed, shifting continuously from the lawyer to the witness.

Finally, facts can be reconstructed and proposed to the listeners (the judge or jury on the diegetic level and the audience on the extradiegetic one) without resorting to traditional narration, but rather to what is left unsaid and implicit.

The analysis of the alternation between the narrative and the paradigmatic mode (Heffer, 2005) in the legal discourse reproduced in fiction has also revealed the popularizing function of narrative. The contextualization provided by a narration is juxtaposed and contrasted with the decontextualization process which places facts and events within abstract and universal categories, rules and paradigms. This contrast between the two modes triggers the association of technical terms specific to the legal profession with facts and stories which, on the contrary, are perceived as similar to the audience's personal experience, therefore favoring familiarization with legal-specific contents.

\section{BIBLIOGRAPHY}

AKASS Kim. \& MCCABE Janet (2007), “Analyzing Fictional Television Genres”, E. Devereux (ed.), Media Studies: Key Issues \& Debates, Los Angeles: Sage, 283-301.

ALTMAN Rick (2008), A theory of narrative, New York: Columbia University Press.

ANESA Patrizia (2011), Courtroom Discourses: An Analysis of the Westerfield Jury Trial, (Unpublished PhD Thesis), Verona: University of Verona.

ARON Roberto, FAST Julius \& KLEIN Richard B. (1996), Trial Communication Skills, Deerfield, Illinois: Clark Boardman Callaghan.

BAMFORD Julia (2012), "Rendering the dismal science more lively: Popularizing Economics in English and Italian", G. Bongo \& G. Caliendo (eds), Language of Popularization / Die Sprache der Popularisierung: Theoretical and Descriptive Models / Theoretische und deskriptive Modelle, Bern: Peter Lang, 23-49.

BERNARDELLI Andrea (2012), “Le forme della serie televisiva”, A.Bernardelli (ed.), Il trionfo dell'antieroe nelle serie televisive, Perugia: Morlacchi, 15-63.

BHATIA Vijay K. (1997), “Genre-Mixing in Academic Introductions”, English for Specific Purposes, 16 (3), 181-196. 
BHATIA Vijay K. (2004), Worlds of Written Discourse: A Genre-Based View, London: Continuum International.

BROoKs Peter (2005), “Narrative in and of the Law”, J. Phelan \& P. J. Rabinowitz (eds), A Companion to Narrative Theory, Malden/Oxford/Victoria: Blackwell, 415-426.

BRUNER Jerome (1990), Acts of Meaning, Harvard: Harvard University Press.

BRUNER Jerome (1991), “The narrative construction of reality”, Critical Inquiry, 18, 1-21.

BURNS Robert P. (2009), The death of the American trial, Chicago: University of Chicago Press.

CALSAMIGLIA Helena \& VAN DIJK Teun A. (2004), "Popularization discourse and knowledge about the genome”, Discourse and Society, 15(4), 369-389.

CAMmiss Steven (2006), "He goes off and I think he took the child: Narrative (re)production in the courtroom", King's Law Journal, 17, 71-95.

CHAEMSAITHONG Krisda (2014), "Dramatic monologues - the grammaticalization of speech roles in courtroom opening statements", Pragmatics, 24(4), 757-783.

CHANDLER Daniel (2000), “An Introduction to Genre Theory”, Media and Communication Studies, < https://www.researchgate.net/publication/242253420_An_Introduction_to_Genre_Theory> (last access: March 28, 2016).

CHAPON Sandrine (2013), “Mise au point sur l'éthique dans les séries télévisées à substrat juridique", Recherche et pratiques pédagogiques en langues de spécialité, 32(2), 104-123.

CIAPUSCIO Guiomar E. (2003), "Formulation and reformulation procedures in verbal interactions between experts and (semi-)laypersons", Discourse Studies, 5(2), 207-234.

COTTERILL Janet (2003), Language and Power in Court: A Linguistic Analysis of the O.J. Simpson Trial, Basinkgstoke / New York: Palgrave MacMillan.

GARZONE Giuliana (2006), Perspectives on ESP and popularization, Milano: CUEM.

GARZONE Giuliana (2012), "News production and scientific knowledge: Exploring popularization as a process", G. Bongo \& G. caliendo (eds), Language of Popularization / Die Sprache der Popularisierung: Theoretical and Descriptive Models / Theoretische und deskriptive Modelle, Bern: Peter Lang.

GENETTE Gérard ([1972] 1980), Narrative Discourse: An Essay in Method, Ithaca: Cornell UP.

GEORGAKOPOULOU Alexandra \& GOUTSOS Dionysis (2000), "Revisiting discourse boundaries: The narrative and non-narrative modes", Text, 20(1), 63-82.

GÜLICH Elisabeth (2003), “Conversational techniques used in transferring knowledge between medical experts and non-experts”, Discourse and Society, 5(2), 253-263.

HEFFER Chris (2005), The Language of Jury Trial: A Corpus-Aided Linguistic Analysis of Legal-Lay Discourse, Houndmills-New York: Palgrave McMillan.

ISANI Shaeda (2004), "The FASP and the Genres within the Genres”, M. Petit \& S. Isani (eds), Aspects de la fiction à substrat professionnel, Bordeaux: Collection Travaux 2025, 121-132.

ISANI Shaeda (2006a), "Revisiting Cinematic FASP and English for Legal Purposes in a Self-learning Environment", Cinéma et Langue de spécialité. Cahiers de l'APLIUT, 25(1), 27-38.

ISANI Shaeda (2006b), "Langue, lecture et littérature populaire : FASP et didactique des langues de spécialité", Cahiers de l'APLIUT, 25(3), 92-106. 
ISANI Shaeda (2009), "Specialised fictional narrative and lay readership: Bridging the accessibility gap", ASp, 56, 45-65.

ISANI Shaeda (2010), "Bench and bar in popular legal fiction. A comparative approach to fictional representations and public perceptions", GRAAT Online, 7, 182-200.

ISANI Shaeda \& CHAPON Sandrine (2015), "A Socio-Cultural Approach to ELP: Accessing the Language and Culture of Law through Fictional Television Series", Alicante Journal of English Studies, 28, 103-118.

LABOV William (1972), "Some principles of linguistic methodology", Language in Society, 1(1), $97-120$.

LABOV William (1977), Language in the Inner City: Studies in the Black English Vernacular, Oxford: Blackwell.

LAUDISIO Adriano (2015), "Diversifying language according to the context: popularizing legal language in TV series”, G. Balirano \& M. C. Nisco (eds), Languaging Diversity: Identities, Genres, Discourses, Newcastle-upon-Tyne: CSP.

LAUDISIO Adriano (2016a), Legal drama and popularization: A micro- and macro-linguistic analysis of the genre (Unpublished PhD Thesis), Naples: University of Naples ‘Federico II'.

LAUDISIO Adriano (2016b), “The Good Wife: intralinguistic rescripting of Special Languages in Audiovisual Products”, M. canepari, G. Mansfield \& F. Poppi, (eds), Remediating, Rescripting, Remaking: Old and New Challenges in English Studies, Parma: Carocci.

LINDQUIST Weyman (1982), “Advocacy in opening arguments”, Litigation, 8(3), 127-142.

NEALE Stephen ([1990] 1995), "Questions of genre”, O. Boyd-Barrett \& C. Newbold (eds), Approaches to Media: A Reader, London: Arnold, 460-72.

O' CONNELL Anne-Marie (2012), “Les séries télévisuelles juridiques américaines : représentations langagières et culturelles d'une communauté professionnelle", Recherche et pratiques pédagogiques en langues de spécialité, 31(2), 113-125.

OLSON Greta (2014), "Narration and narrative in Legal Discourse", The living book of Narratology, < http://www.lhn.uni-hamburg.de/article/narration-and-narrative-legal-discourse> (last access: June 07, 2017).

PETIT Michel (1999), “La fiction à substrat professionnel : une autre voie d'accès à l'anglais de spécialité”, Asp, la revue du GERAS, 23(26), 57-81.

PROPP Vladimir ([1928] 1968), Morphology of the folktale, Austin: University of Texas Press.

SPIECKER Shelley C. \& WORTHINGTON Debra L. (2003), "The influence of opening statement/closing argument organizational strategy on juror verdict and damage awards", Law and Human Behavior, 27(4), 437-456.

SWALES John (1990), Genre Analysis. English in Academic and Research Settings, Cambridge, UK:

Cambridge University Press.

TANFORD J. Alexander (2002), The Trial Process: Law, Tactics, and Ethics (3rd ed.), Newark, NJ:

LexisNexis.

TODOROV Tzvetan ([1971] 1977), The Poetics of Prose, Oxford: Blackwell.

TODOROV Tzvetan \& BERRONG, Richard M. (1976), “The origin of genres”, New Literary History, 8(1), 159-170. 
VILLEZ Barbara (2005), Television and the legal system, London/New York: Routledge.

\section{NOTES}

1. Loosely translated as: "The general feature of telling a story which prompts the reader to want to get to the denouement. [...] The primary quality of an author is thus his/her ability to tell a story; [...] suspense is an essential element." (My translation).

2. Loosely translated as: "As a result of what is narrated about the principal protagonist's profession and the starting point of the story, the FASP plot is essentially 'endogenous', i.e. it arises from within the professional reality which created it." (My translation).

3. Contrary to "vintage" legal drama like Perry Mason, in contemporary legal dramas there is a strong tendency to mix the lawyers' professional and private lives (Villez, 2005) and to portray lawyers as counter-archetypal, faulted human beings. Similarly, clients too are often discovered to be guilty or morally reprehensible and judges are demystified (Isani, 2010: 186-189). It is in such multifaceted portrayals and in relation to their own lives that the audience finds an increased interest in the fictional product.

4. Bamford (2012: 28) in fact, defines recontextualization as involving "the knowledge in a source text being removed from its original context and repositioned while at the same time undergoing a change in its communicative purpose".

5. This study is based on the assumption that FASP genres play an important role in the communication of knowledge, as with ESP teaching: Isani (2006a, 2006b) has demonstrated the utility of the applications of FASP to ESP teaching not only on the level of specialized discourse and language, but also on that of specialized content and culture.

6. Elaborated by Bruner (1990) and first applied to discourse studies by Georgakopoulou and Goutsos (2000).

7. As premised earlier, the excerpts drawn from legal drama are not always entirely representative of the reality of a courtroom procedure. For example, in this case, the full narration could hardly be developed, since:

a) in line 7 the opposing party would have objected to a question calling for speculation (the witness is asked to guess instead of giving facts);

b) in line 8 the answer is vague and therefore objectionable;

c) in lines 11-13 counsel is testifying and posing a leading question.

This line of questioning would be subject to objections since they violate the Federal Rules of Evidence.

8. Similar to the excerpt in Table 3, the line of questioning contained in this examination contains some objectionable points which are overlooked in the episode:

a) unless it is a cross-examination, the question in line 14-16 would be considered leading;

b) the witness's answer is vague;

c) the witness is being badgered.

However, in this case, since Mr. Santana is acting as his own lawyer and is testifying, the absence of objections is justifiable. 


\section{ABSTRACTS}

Studies in ESP have recently expanded from investigating specialized language in use in professional environments to encompassing their use in different contexts with other purposes, among which artistic and entertainment ones. In particular, studies on FASP (Fiction à Substrat Professionnel), i.e. fictional novels based on specific professional figures and fields, or the more recent studies in specialized TV series, offer a new perspective to analyzing how ESP intertwines with fictional narrativity.

Among the most common FASP genres, legal FASP television series represent a good example of how this multimodal fictional genre exploits ESP by embedding the principles, procedures, professionals and the related terminology of the United States courtrooms and law firms into the heart of the plot.

This paper sets out to describe the function of narration in legal drama. Drawing upon Labov's 1977 'evaluation' model, a corpus of scenes of narrations in and out of the courtroom drawn from three legal dramas (Boston Legal, Suits and The Good Wife) is analyzed, looking at narration as constitutive of the sub-genres embedded in legal drama (e.g. witness examination) and as a means of popularizing legal-specific contents.

In reference to this last point, a number of popularization strategies are identified which rely on the 'narrative mode', a way of expressing concepts through contextualization, further divided into actional, intersubjective and normative sub-modes, which is shown to be constitutive of legal-lay discourse. In particular, the 'shift' from 'narrative' to the 'paradigmatic' mode shows how narration can contribute to the popularization of legal-specific contents.

Au cours des dernières années, la recherche en anglais de spécialité a évolué de l'étude de la langue de spécialité utilisée dans l'exercice d'une profession vers la prise en compte des contextes ayant d'autres objectifs dont l'art et le divertissement. Plus particulièrement, les études dans le domaine de la fiction à substrat professionnel ou la FASP - des romans, des films et des séries mettant en fiction des professionnels et des environnements professionnels représentent une nouvelle perspective d'analyse de la façon dont l'anglais de spécialité s'entremêle avec le récit fictionnel.

Parmi les genres les plus répandus, la FASP juridique télévisuelle représente un exemple éclairant de la façon dont ce genre fictionnel multimodal exploite l'anglais de spécialité en intégrant les principes, procédures, professionnels et terminologie des tribunaux et cabinets d'avocats américains au cœur de l'intrigue.

Cette étude se propose de décrire la fonction du récit narratif dans les séries juridiques. En s'inspirant du modèle d'« évaluation » de Labov (1977), nous analysons un corpus de récits situés à l'intérieur et l'extérieur du prétoire tirés de trois séries juridiques américaines (Boston Legal, Suits et The Good Wife) à travers la notion du récit comme un élément constitutif des sous-genres enchâssés dans le récit fictionnel (comme, p. ex., l'audition des témoins) et comme un moyen de vulgarisation des contenus spécialisés. Dans ce contexte, nous identifions un certain nombre de stratégies qui dépendent $d u$ "mode narratif», une manière d'exprimer des concepts par la contextualisation et ses sous-modes (actionnel, intersubjectif, normatif...) qui sont constitutifs du discours juridique expert-profane. En particulier, le glissement du mode « narratif » vers le mode 
"paradigmatique» démontre la façon dont le récit peut contribuer à la popularisation des contenus juridiques.

INDEX

Keywords: FASP, ESP, legal drama, fictional narration, popularization of legal discourse Mots-clés: FASP, anglais de spécialité, séries télévisuelles juridiques, récit spécialisé juridique, popularisation

\section{AUTHOR}

ADRIANO LAUDISIO

Università di Napoli Federico II (Italia) 